\title{
PERKEMBANGAN DAN KONSEP DASAR MANAJEMEN HUMAS DALAM DUNIA PENDIDIKAN : TINJAUAN HISTORIS
}

\begin{abstract}
Abdul Hadi*
Abstract: This journal discusses the history of development, definition, function, objective and scope of public relations management globally then we are required to understand and glance back the history of the emergence of "Public Relation" which originated from the crisis strikes the workers of the industry that occurred in United States in 1906. The practice of public relations or Public Relations has evolved and continues to grow consciously or not, with the number of institutions and companies are growing, competition is increasingly tight in grabbing the public's attention, many ways done by institutions or companies to expose the program or policies, even the excellence of the institution, its main purpose is tersampaikanya to the public, by empowering Public relations or Public Relations, which in this case public relations that must relate and maintain direct communication with the community. People are certainly more interested in the offer of quality programs that are packaged well and interesting. Moreover, being in the world of information is very fast and open, an institution or company may not just be silent waiting to get public attention.
\end{abstract}

Keywords: Management, Public Relations, History, Scope

\section{A. Pendahuluan}

Pendidikan merupakan ladang investasi terbesar dalam membangun dan membentuk manusia seutuhnya (insanul kamil). Sentuhan pendidikan diyakini mampu membentuk sumberdaya manusia (human resources) yang beradab dan berkualitas. ${ }^{1}$ Oleh karena itu, lembaga pendidikan hendaknya perlu mendapatkan sentuhan manajemen yang baik dan professional, sehingga mampu survive dan berdaya saing. Para manajer dan unsur pendidikan lainnya dituntut mencari dan menerapkan suatu strategi manajemen baru yang dapat mendorong perbaikan mutu di lembaganya. ${ }^{2}$ Salah satu manajemen yang dapat digunakan dalam hal ini adalah manajemen humas atau public relation.

Public Relations atau yang sering disingkat PR ialah kumpulan dari beberapa ilmu sertadiantaranya adailmu sosial seperti contohnya Ilmu psikologi,politik sosiologi, ekonomi, komunikasi, sejarah, yang melalui perkembangannya, teknologi information sudah menjadi bagian dari Public

\footnotetext{
* Dosen tetap Universitas Nurul Jadid Paiton Probolinggo, Email: dityabdul@ gmail.com

1 Hasan Baharun, 'PENDIDIKAN ANAK DALAM KELUARGA; TELAAH EPISTEMOLOGIS', Pedagogik, 3.2 (2016), 96-107.

${ }^{2}$ Zamroni Hasan Baharun, Manajemen Mutu Pendidikan : Ikhtiar Dalam Meningkatkan Mutu Pendidikan Madrasah Melalui Pendekatan Balanced Scorecard (Tulungagung: Akademia Pustaka, 2017). iv
} 
Relations $^{3}$. Di Indonesia public realations lebih dikenal dengan Humas atau Hubungan Masyarakat. Peranan humas bagi sebuah lembaga menempati posisi yang penting. Public Relation atau humas berperan dalam mengkomunikasikan program kerja sebuah lembaga kepada publik. Namun sayangnya, hampir kebanyakan lembaga yang ingin berkembang belum bisa memaksimalkan peranan humas. Humas masih dianggap sebagai penyampai informasi kebutuhan antar lembaga atau sebagai pengantar surat saja. Permasalahan ini mungkin akibat dari kurangnya pemahaman terhadap konsep humas yang utuh secara keseluruhan. ${ }^{4}$

Pada saat ini, public relations(PR) dapat dinyatakan sangat menentukan kelangsungan hidupsuatulembagaatau perusahaan, karena public relations berperan untuk menumbuh kembangkanhubungan yang baik antara setiap organisasi dengan masyarakat atau publik sebagai sasaran dari kegiatan public relations itu sendiri ${ }^{5}$. Disadari atau tidak, dengan banyaknya lembaga dan perusahaan yang semakin bertumbuhan, persaingan yang semakin ketat dalam merebut perhatian masyarakat semakin gencar dan sering dilakukan. Masyarakat tentu lebih tertarik pada tawaran-tawaran program berkualitas yang dikemas dengan baik dan menarik. Apalagi berada dalam dunia informasi yang sangat cepat dan terbuka, sebuah lembaga atau perusahaan tidak mungkin hanya diam saja menunggu untuk mendapatkan perhatian public ${ }^{6}$.

Terdapat beberapa hal yang perlu dipahami mengenai public relations ini, karena masih terlalu banyak orang yang belum bisa memahami sepenuhnyaapa yang dimaksud denganpublic relations dan penerapannya dalam dunia kerja. Karena itu akan dijelaskan lebih lanjut mengenai sejarah perkembangan humas, definisi manajemen humas, tujuan dan fungsi manajemen humas,unsur dasar manajemen humas danruang lingkup manajemen humas agar dapat dipahami dengan baik.

\section{B. Pembahasan}

\section{Perkembangan Humas : Tinjauan Historis}

Sejarah berbicara bahwa awal mula manajemen humas ini muncul berkenaan dengan sebuah metode "Public Relations" ketika menghadapi puncak krisis pada tahun 1906. Saat itu terjadilah aksi mogok kerja para buruh diindustri pertambangan batu bara di Amerika Serikat. Akibatnya industry batu bara terbesar itu terancam mengalami kelumpuhan produksi ${ }^{7}$.

\footnotetext{
${ }^{3}$ Ahmad Fauzi, 'Pengembangan Human Relation Perspektif Nilai-Nilai Al-Qur'an', Mutawatir UIN Sunan Ampel Surabaya, 1.2 (2015), 168-79.

4 Akmal Mundiri, 'STRATEGI LEMBAGA PENDIDIKAN ISLAM DALAM MEMBANGUN BRANDING IMAGE', Pedagogik, 3.2 (2016), 58-72.

5 Ahmad Fauzi, 'Diskursus Pemikiran Dan Model Pengembangan Budaya Organisasi Noble Industry di Lembaga Pendidikan Islam', Studi Islam Madinah IAI Tabah, 16.Pendidikan Islam (2016).

${ }^{6}$ Ahmad Fauzi, 'Membangun Epistemologi Pendidikan Islam Melalui Kepemimpinan Spiritual : Suatu Telaah Diskursif', Journal Empirisma, STAIN Kediri, Vol. 24.No 2 (2015), 15567.

${ }^{7}$ Ruslan Rosady, Praktik Dan Solusi Public Relations Dalam Situasi Krisis Dan Pemulihan (citra.Jakrta:Gahlia Indonesia, 1997). 15
} 
Saat itu Ivy Letbetter Lee yang notabene seorang jurnalis muncul sebagai Tokoh Public Relation/ Humas untuk pertama kalinya. Beliau merekomendasikan manajemen humas sebagai solusi untuk mengatasi permasalahan yang sedang terjadi di industry batu bara tersebut akibat mogok masal para pekerja yang meminta kenaikan gaji. Atas upayanya ini ia diangkat menjadi The Father of Public Relations.

Agar supaya permasalahan yang terjadi itu dapat terpecahkan, maka Ivy Lee memberikan beberapa usulan yang merupakan inovasi besar dalam peran PR/Humas untuk mengatasi permasalahan besar yang terjadi saat itu melalui konsep teori dasar sebagai berikut :

a. Menciptakan menejemen humas untuk mengatur perkembangan informasi secara terbuka.

b. Menjalin kerjasama dengan pihak pers.

c. Menjadi pimpinan perusahaan dan menjadi pengambil keputusan tertinggi ( Decision Maker) dan ( Polisi Maker ).

d. Memilki kekuasaan penuh dalam menjalankan fungsi dan berkontribusi sebagai pejabat Humas untuk menata Humas

e. Manajemen humas harus bersifat informasi terbuka (Open Communication) terhadap masyarakat, pekerja maupun pihak pers.

Berikut ini adalah gambaran secara umum kronologis perkembangan Public Relations:

Pada abad ke-19

: Public Relations di Amerika dan Eropa merupakan program studi yang mandiri didasarkan pada perkembangan Ilmu pengetahuan dan teknologi,

Tahun ke 1865 s/d 1900 : Masih menganggap seluruh public bodoh,

Tahun 1900 s/d 1918 : informasi dan pelayanan sudah diberikan kepada Publik,

Tahun 1918 s/d 1945 : Memberikan pendidikan kepada Publik dan menghargainya secara penuh,

Pada Tahun 1925 : Humas ( Public relations ) merupakan pendidikan resmi tertinggi di New York,

Tahun 1928 : Humas ( Public Relations) sudah mulai di wajibkan sebagai mata kuliah pada fakultas pendidikan di belanda,

$1945-1968$

: Sudah mulai banyak yang mengetahui dan terbuka untuk Publik Relations ( Humas ),

Pada tahun 1968 : Negara Belanda mengalami perkembangan yang sangat pesat karena sudah menuju ke arah yang ilmiah dan melakukan penelitian yang berkelanjutan, sedangkan di amerika humas terfokus kearah bisnis.

1968-1979

: Publik relations ( Humas ) banyak dikembangkan di berbagai bidang dan pendekatan tidak hanya dari satu aspek saja, 
$1979-1990$

1990-sekarang

\section{Manajemen Humas}

Profesional/internasional memasuki globalisasi dalam perubahan mental dan kualitas,

: Perubahan mental, kualitas, pola pikir, pola pandang,sikap dan pola perilaku secara nasioal/internasional,membangun kerjasama secara lokal, nasional, internasional,saling belajar di bidang politik, ekonomi, sosial budaya,Iptek, sesuai dengan kebutuhan era global/informasi

Manajemen merupakan suatu proses/ ilmu untuk merencanakan, mengorganisasikan, memimpin, dan mengendalikan upaya organisasi dengan segala aspeknya agar tujuan organisasi tercapai secara efektif dan efisien. ${ }^{8}$ Sedangkan public relations yang sering kita sebut dengan humas atau hubungan masyarakat mempunyai dua pengertian. Pertama, public relations diartikan sebagai technique of communication (teknik komunikasi) dan kedua, Public Relations diartikan sebagai method of communication (metode komunikasi) ${ }^{9}$. Public relation ialah peran manajemen untuk menggapai suatu goal tertentu yang memiliki program kerja pasti, jelas dan terperinci, mencari fakta, rencana, komunikasi sampai mengasesmen seluruh prestasi yang sudah dicapai ${ }^{10}$. Hubungan masyarakat merupakan sebuah seni ilmu social dimana ilmu tersebut mencakup analisa, perencanaan, penentuan, pengarahan, pelaksanaan program-program terencana yang dapat memenuhi kepentingan atau tujuan pada instansi atau organisasi dengan masyarakat terkait.

Dari penjabaran di atas dapat disimpulkan bahwasanya definisi umum public relation ialah suatu fungsi manajemen yang menggeluti penilaian pada sikap public yang dalam hal ini masyarakat, pengidentifikasian kebijaksanaan dan cara dimana seseorang/ kelompok melakukan demi kepentingan masyarakat, serta membuat rencana dan melaksanakan program kerja untuk menarik perhatian, pengenalan, pengetahuan, partisipasi serta support dari masyarakat luas. Karena sesungguhnya arti dari humas merupakan suatu pola untuk menjadi tetangga serta warga yang baik supaya dapat diterima oleh lingkungan.

Jadi Konsep Public Relations sebenarnya berkenaan dengan kegiatan penciptaan pemahaman melalui pengetahuan, dan melalui kegiatan-kegiatan tersebut akan muncul perubahan yang berdampak ${ }^{11}$. Dari pemahaman tersebut diharapkan public relation mampu meningkatkan mutu pendidikan pada

\footnotetext{
${ }^{8}$ Hasan Baharun, 'Manajemen Kinerja Dalam Meningkatkan Competitive Advantage Pada Lembaga Pendidikan Islam', At-Tajdid: Jurnal Ilmu Tarbiyah, 5.2 (2016), 243-62.

${ }^{9}$ N U R Shaff Afifa, Lidya Wati Evelina and Dra Mm, 'Strategi Public Relations Dalam Membangun Customer Relationship Management Di Pt . Sungwon Button Indonesia', 2012.

${ }^{10}$ Dr.Abdul Rahmad, MANAJEMEN HUMAS (Media Akademi Ruko Jambusari 7A Yogyakarta 55283, 2016).

${ }^{11}$ Nurul Candrasari Masykuri, 'PERAN PUBLIC RELATION TAK SEKEDAR FUNGSI TEKNIS’, HUMANIORA, 2.9 (2011), 353-59.
} 
organisasi kependidikan. ${ }^{12}$ Public Relations menyangkut suatu bentuk komunikasi yang berlaku untuk semua organisasi (non profit - komersial, publik- privat, pemerintah - swasta). Artinya Public Relations jauh lebih luas ketimbang pemasaran dan periklanan atau propaganda, dan telah lebih awal.

\section{Manajemen Humas : Tujuan dan Fungsinya}

Adapun tujuan dan fungsi pokok manajemen humas adalah sebagai berikut :

a. Planning (Perencanaan)

Perencanaan sebagai fungsi manajemen dilakukan pada tahap pertama sebelum melaksanakan kebijakan, program dan kegiatan.Perencanaan sebagai cetak biru (blu print) atas kebijakan, program dan kegiatan-kegiatan organisasi ${ }^{13}$.

Perencanaan merupakan upaya untuk menentukan program kegiatan yang ingin dilakukan serta bagaimana cara mencapai tujuan organisasi. Perencanaan sebagai suatu proses mempersiapkan sesuatu yang akan di lakukan pada saat selanjutnya untuk meraih tujuan yang sudah di sepakati. Simpelnya, perencanaan merupakan usaha yang terus menerus secara sadar dan terorganisir dilaksanakan agar supaya dapat memilih alternative yang paling baik untuk menggapai tujuan bersama $^{14}$.

Adapun fungsi dari perencanaan ialah meminta para manajer untuk membuat keputusan-keputusan tentang 4 (empat) unsur rencana yang fundamental, yaitu sasaran, pelaksanaan,sumber daya dan tindakan. "The function of planning is to ask managers to make decisions about 4 (four) elements of a fundamental plan, ie goals, execution, resources and actions. " 15 .

Dari beberapa pengertian perencanaan yang telah dikemukakan ada beberapa persamaan pendapat menyangkut beberapa as-pek perencanaan $^{16}$.

Aspek-aspek perencanaan tersebut yaitu:

1) Perencanaan sebagai suatu peroses.

2) Perencanaan berorientassi masa depan.

3) Perencanaan berorientasi pada pencapaian tujuan organisasi.

4) Perencanaan menjabarkan kegiatan-kegiatan.

\footnotetext{
${ }^{12}$ Hasan Baharun, Management Of Quality Education In Pesantren: The Study of the Education Quality Improvement Pesantren by Strategy Management Approach (Malang: 2nd INTERNATIONAL CONFERENCES ON EDUCATION AND TRAINING (ICET), UM Malang., 2016).

${ }^{13}$ Stoner, James, A.F., Freemen , R.W. dan Gilbert, 'Management' (Pritice-Hall, New Jeresey., 1996), p. 120.

${ }^{14}$ Stoner, James, A.F., Freemen , R.W. dan Gilbert.

${ }^{15}$ John M. Ivancevich, 'Human Resource Management' (International Edition. (New York: McGraw-Hill \& Irwin, 2001), p. 51.

${ }^{16}$ Jr Schermerhorn, John R., 'Management Eighth Edition.' (New York: John Wiley \& Sons, Inc, 2005), p. 15.
} 
5) Perencanaan sebagai kegiatan untuk mengidentifikasikan sumber daya yang dapat menunjang pelaksanaan kegiatan-kegiatan.

6) Perencanaan merupakan kegiatan mempersiapkan sejumlah alternatif.

b. Pengorganisasian

Pengorganisasian adalah fungsi manajemen yang membagi tugas- tugas yang harus dikerjakan, serta menata sumberdayasumberdaya yang ada untuk mengerjakan tugas-tugas tersebut.Fungsi pengorganisasian termasuk seluruh kegiatan manajerial yang menerjemahkan rencana kegiatan yang diperlukan ke dalam sebuah struktur tugas dan kewenangannya.

Dalam artian praktis, fungsi pengorganisasian meliputi: (1) perancangan tanggung jawab dan kewenangan setiap jabatan individual, dan (2) penetapan jabatan-jabatan tersebut dikelompokkan dalam bagian-bagian tertentu.

Hasil dari fungsi pengorganisasian adalah struktur organisasi.

1) Penentuan staf atau staffing merupakan kegiatan yang dipusatkan pada manajemen sumber daya manusia.

2) Pemimpinan atau leading.

3) Pemberian motivasi, motivating.

4) Pengendalian.

c. Pelaksanaan (Aktuating)

Pelaksanaan disini ialah tindakan atau perbuatan untuk menjalankan sebuah program yang sudah direncanakan.

d. Pengawasan/Monitoring Dan Evaluasi

Monitoring merupakan suatu kegiatan yang bertujuan untuk memaparkan informasi tentang sebab akibat dari sebuah kebijakan yang tengah dilaksanakan. Monitoring akan dilaksanakan disaat sebuah kebijaksanaan diterapkan, hal ini dibutuhkan agar supaya kesalahan yang terjadi dapat segera ditemukan dan segera diatasi, sehingga akan memperkecil resiko yang lebih besar terjadi. ${ }^{17}$

Monitoring bertujuan untuk menjaga agar kebijakan yang diterapkan dalam sebuah lembaga/organisasi dapat berjalan sesuai dengan tujuan yang sudah direncanakan dan dapat menemukan kesalahan sekecil mungkin hingga tidak ada resiko yang lebih besar lagi.Monitoring juga bertujuan untuk memodifikasi dan merubah system kebijakan jika dirasa hasil monitoring membutuhkan perubahan tersebut. Selain monitoring juga diperlukan evaluasi, dimana evaluasi tersebut diambil dari bahas inggris "EVALUATION" yang memiliki arti suatu tindakan atau kegiatan untuk menilai kinerja suatu kebijakan, evaluasi ini akan dilaksanakan jikalau kebijakan tersebut telah berjalan dengan waktu yang cukup.

17 Akmal Mundiri, 'Organizational Culture Base On Total Quality Management In Islamic Educational Institution', ADRI International Journal Of Islamic Studies and Social Sciences, 1.1 (2017), 1-11. 
Evaluasi ialah proses yang dilakukan untuk menilaibagaimanasebuah program Public Relation yang sudah disusun telahdikelola dengan efektif. Evaluasi ini akan melihat apakah program telah dilaksanakan sesuai dengan panduan yang direncanakan atau tidak. Sedangkanevaluasi hasil menilai efek apa yang didapat dari pelaksanaan program humas,apakah sudah memenuhi tujuan atau belum. Penilaian atau evaluasi merupakan penentuan derajat kualitas berdasarkan indikator yang ditetapkan terhadap penyelenggaraan pekerjaan. $^{18}$

Evaluasi bertujuan untuk menentukan tingkat kerja dalam suatu kebijakan, mengukur tingkat efisiensi dalam kebijakan. Mengukur kualitas output dari suatu kebijakan, mengukur dampak positif dan negative dari suatu kebijakan, mengetahui jika terjadi suatu penyimpangan-penyimpangan dengan cara mengadakan perbandingan tujuan, sasaran dengan target yang sudah tercapai.

Evaluasi sebagai input/masukan bagi tahapan kebijakan kedepan suapaya dapat menghasilkan kebijakan yang lebih baik darisebelumnya $^{19}$. Evaluasi merupakan penyediaan information yang bisa dijadikan sebagai salah satu pertimbangan untuk membuat keputusan $^{20}$.

\section{Unsur Dasar Kehumasan}

Ketika kita sudah mengetahui sejarah dan pengertian dari manajemen humas, tidak kalah pentingnya kita harus mempersiapkan unsur- unsur manajemen Public Relation yang pastinya terlibat dalam mensukseskan tujuan yang paling baik. Menurut George Terry, salah satu praktisi public relation mengemukan tentang unsur-unsur yang dibutuhkan agar tercapainya gol yang maksimal $^{21}$ :

a. Men and Women ialah manusia laki laki dan perempuan salah satu pihak yang memerankan peranan penting atas keberhasilan kinerja manajemen dan terlibat langsung dalam perjalanan/proses manajemen tersebut.

b. Material atau alat yang diperlukan yaitu melibatkan barang-barang atau sesuatu yang harus kita beli dan dipersiapkan agar supaya bisa menunjang keberhasilan dari proses manajemen tersebut.

c. Machines atau sarana prasarana yang kita gunakan yaitu meliputi seluruh alat atau barang yang mendorong untuk melaksanakan proses dalam manajemen.

\footnotetext{
${ }^{18}$ Hasan Baharun, 'Penilaian Berbasis Kelas Pada Pembelajaran Pendidikan Agama Islam Di Madrasah', MODELING: Jurnal Program Studi PGMI, 2016.

19 R.L. Thorndike and E.P.Hagen, 'Measurement and Evaluation in Teaching .' (Englewood Cliffs New Jersey: Prentice-Hall, Inc, 2009), p. 123.

20 'National Study Committee on Evaluation Dalam Stark Dan Thomas (1994:12) Lihat Juga Jody Fitzpatrick. Evaluation in Action: Interviews With Expert Evaluators.' (Los Angeles: SAGE Publication, 2009), p. 43.

${ }^{21}$ Yayasan Trisakti, Dasar - Dasar Manajemen (Jakarta:Grasindo, 2008). Hlm 98
} 
d. Methods ialah teknik atau cara yang kita pakai dalam menjalankan proses manajemen agar supaya sesuai dengan apa yang kita harapkan.

e. Money atau dana ialah anggaran yang kita butuhkan harus benar benar susuai dengan program yang sudah kita rencanakan agar supaya tercapainya tujuan maksimal.

f. Market atau pasar ialah khalayak yang di jadikan sasaran untuk menjalankan proses kegiatan manajemen.

Ada 4 unsur falsafah yang bisa kita jelaskan dari pengertian humas diatas yaitu :

a. Humas ialah prinsip manajemen yang sifatnya sosial

b. Humas ialah wujud dari prinsip terhadap tataran kebijakan.

c. Humas ialah komunikasi 2 arah yang sifatnya menunjang atas keberhasilan kebijakan program dari manajemen humas yaitu meliputi dalam hal informasi,penjelasan dan promosi agar terjadi pengertian yang baik.

d. Public relation salah satu cara bagaimana bisa menciptakan atau membuat opini masyarakat/public.

Ada pula unsur falsafah yang sangat berpengaruh dari bidang praktik dan teori :

a. Public relation dijadikan sebagai salah satu upaya untuk mempengaruhi kemauan perorangan dan kelompok agar supaya bisa merubah minset atau pola pikirnya secara global oleh pemegang tampuk kekuasaan atau pemerintah.

b. Public relation juga dijadikan ajang untuk mendorong atas majunya dibidang perekonomian. Prinsip atau falsafah seperti ini hanya digunakan oleh kelompok usaha yang mencari keuntungan.

c. Public relation dapat menggunakan ilmu pengetahuan yang seluas luasnya agar supaya bisa mencapai tujuan yang maksimal.

d. Visi dan misi yang kita rencanakan harus disesuaikan atau bahkan jauh dua kalilipat dari kebutuhan masyarakat. ${ }^{22}$

Sedangkan Ruang lingkup Humas/Public Relations lebih luas daripadahanya penyelenggaraan relations yang baik antara pihak organisasi atau institusidengan media. Humas/Public Relations harusmelibatkan dari semua aspekyaitu memperhatikan organisasi atau institusi swasta, public, komersial maupun non komersil. Pada awalnya humas atauPublic Relations bertujuan menanamkan pemahaman goodwill, pemberian kepercayaan dan penghargaan kepada lembaga atau institusi yang terlibatantar pihak internal ataupun eksternal di dalam ruang lingkupmasing-masing. berikut :

Widjaja, mengungkapkan bahwa ruang lingkup humas pada sebagai

a. Pengolahan dan pengumbulan data

${ }^{22}$ Akmal Mundiri, 'KOMITMEN ORGANISASIONAL SUMBER DAYA MANUSIA DALAM MENINGKATKAN MUTU PENDIDIKAN PESANTREN', Pedagogik, 3.1 (2015), 88105. 
Pengolahan dan pengumpulan data bermanfaat untuk memberikan informasi kepada lembaga dan khalayak umum serta bisa sebagai umpan balik informasi dari lembaga dan masyarakat

b. Penerangan

Dalam hal ini tugasnya memberikan informasi kepada masyarakat melalui media massa berkaitan tentang kebijakan dan pelaksanaan program kerja lembaga atau institusi tersebut.

c. Publikasi

Semua kebijakan dan kegiatan yang dilakukan oleh lembaga atau institusi harus dipublikasikan.

Jefkins, dalam buku Public Relations, ruang lingkup dibedakan dalam 2 bagian diantaranya ialah sebagai berikut:

1) Public Internal, menjaga relasi kedalam

2) Public Eksternal,menjaga relasi keluar.

Effendy, dalam buku Kamus Komunikasi, membagi target kegiatanhumas/Public Relations, menjadi 2 bagian diantaranya ialah :

a. Public Internal Relations ialah orang-orang terlibat didalam organisasi dari pegawai paling atas sampai paling bwah.

b. Public Ekternal Relations ialah orang-orang yang keberadaannya di luar lembaga atau organisasi tetapi masih mempunyai hubungan dengan organisasi atau lembaga tersebut.

Seorang Public Relations seharusnya mempunyai kemampuan atau caraberkomunikasi yang baik dalammenjalankan kegiatan - kegiatan yang sudah di programnya dengan sikap profesional, sehingga bisa menciptakan relations/hubungan yang baik dan bisa menjangkau ruang lingkup public relations yang sangatluas. Dari pengertian yang sudah diurai diatas kita bisa mengambil kesimpulan secara global,bahwa batasan ruang lingkup dari humas/Public Relationsdapat kita bagi menjadi 2 bagian, yaitu External Public Relation dan Internal Public Relations

a. Internal Public Relations

Internal Public Relations pada hakekatnya ialah hubungan atau relasi antar pegawai atau karyawan pada suatu instansi atau lembaga(staff relations) atau antar anggota disebuah lembaga/organisasi dengan menggunakan komunikasi internal.

Effendy dalam bukunya Human RelationsDanPublic Reations mengemukakan bahwa: Internal Public Relations adalah kegiatan yang berencana, membina dan memelihara sikap budi yang dilakukan oleh atasan dengan bawahan dan bawahan dengan bawahan didalam suatu organisasi.

Definisi Internal public relations, Muhammad dalam bukunya Komunikasi Organisasi adalah kegiatan yang terencana yang ditujukan kepada anggotanya didalam suatu organisasi.

Mengingat pentingnya tugas Internal Public Relations, terutama yang bersifat formal, ada tugas yang perlu diperhatikan agar pelaksanaan kegiatan Internal Public Relations dapat bejalan dan dapat dilaksanakan dengan baik, setiap karyawan atau pegawai harus berupaya menjaga citra 
perusahaan atau instansi, menciptakan suasana kerja yang baik, salah satunya yaitu membina hubungan harmonis antara karyawan/pegawai.

Kemudian Internal Public Relations dapat mendukung kegiatan perusahaan seperti menerima dan melaksanakan tugas yang telah diberikan pihak manajemen dengan penuh tanggung jawab serta melaksanakan pengarahan berupa pemberian motivasi kepada karyawan.

Breannan di kutip Effendy, didalam bukunya "Ilmu Komunikasi Teori dan Praktek" memberikan pengertian tentang Comunication Internal sebagai berikut: Sharing gagasan antara admin dan staf/karyawan didalam sebuah lembaga atau perusahaan yang bisa menimbulkan terjadinya kesempurnaan terhadap program dan struktur yang uniq dari organisasillembaga tersebut dan sharing gagasan vertical maupun horizontal yang menimbulkan pekerjaan langsung (Manajemen dan operasi).

Komunikasi Internal ialah sering gagasan antara atasan kepada karyawan/bawahan, bawahan kepada atasan maupun bawahan dengan bawahan yang lainnya, hingga dapat terjalin kerjasama yang baik dengan keseluruhan karyawan/pegawai.

Public internal merupakan kelompok yang ada pada suatu perusahaan/instansi dan melakukan aktivitas dalam perusahaan tersebut. Kinerja Public Relations dalam suatu perusahaan atau instansi adalah sebagai mediator komunikasi antara karyawan dengan pimpinan dan akan sangat membantu perkembangan perusahaan.

Palapah dan Syamsudin dalam buku Studi Ilmu Komunikasi mengatakan bahwa Internal Relations Terdiri dari :

1) Employee Relations ialahrelasi yang memelihara manajemen dengan pegawai secara formal.

2) Human Relations ialahrelasi yang memelihara antara pegawai dengan pegawai secara tidak formal, sebagai mahluk tuhan/manusia

3) Labour Relations ialahrelasi yang memelihara antara direksi manajemen dan karyawan lembaga atau perusahan guna menyelesaikan permasalahan yang ada diantara keduanya.

4) Stockholder Relations, Industrial relations dan sebagainya sesuai dengan sifat dan kebutuhan institusi/perusahaan.

Kita bisa menciptakan hubungan yang harmonis dan selaras antara public internal dalam suatu organisasi atau instansi, apabilakita sudah bisa membangun komunikasi dua arah yang efektif antara pimpinan dan pegawai.Adanya Two way Communication sangatlah penting hal ini untuk menghindari kesalah pahaman diantara kedua belah pihak.

b. Eksternal Public Relations

Di dalam kamus "Funk and Wagnall, Kamus Desk Standar Amerika" di mana Anggoro mengutip kedalam bukunya yang berjudul "Profesi,Teori Kehumasan dan aplikasinya di Indonesia", menyampaikan bahwa pengertian dari Eksternal Public Relations ,ialah : Segenap teknik dan kegiatan yang dipakai oleh sebuah individu atau organisasi agar 
supaya bisa memelihara dan menciptakan sikap serta tanggapan yang paling baik.

Berikut adalah eksternal public relations secara global dalamperusahaan atau organisasi: Press public, Government public,Community public,Supplier public,Customer public,Consumer public,Educational public, General public

Publik eksternal ialah mereka yang keberadaannya tidak ada didalam perusahaan atau organisasi, namun mempunya relasi dengan lembaga atau perusahaan tersebut. Ada banyak khlayak yang mirip kegiatannya dengan kegiatan organisasi atau perusahaan, seperti yang dituangkan oleh Effendi, didalam bukunya "Hubungan Manusia dan Hubungan Masyarakat,",ialah:

1) Customer Relations: sebuah perusahaan atau lembaga dikatakan sukses apabila bisa mendapatkan pelanggan tetap dan selalu mengadakan komunkasi berkelanjutan secara intens.

2) Community Relations menjaga hubungan dengan masyarakat sekitar agar supaya mendapat perhatian penuh dari masyarakat tersebut perlu dilakukan.

3) Government Relationsmenjaga hubungan yang baik dengan pemerintah sangat perlu dilakukan dengan cara menjaga komunikasi agar selalu diberikan kelancaran dalam melaksanakan program yang di buat . Apabila dikemudian hari terdapat kendala kendala yang dihadapi atau kesulitan kita dengan mudah menyelasikannya karena kita sudah menjalin hubungan yang baik dengan pemerintah.

4) Press Relations hungan dengan pers disini adalahkita artikan yang sangat luas, yaitu seluruh media massa. Hubungan ini sengaja kita pelihara agar supaya lancar dalam mempublikasikan program atau kebijakan yang sudah kita susun.

\section{Sejarah Perkembangan dan Konsep dasar Manajemen Humas}

Sejarah mengatakan bahwa humas hanya sebagai pengantar surat, tukang si'ar dan hanya menjalin kerjasama dengan media masa saja yang mana pada kenyataannya ruang lingkup humas sangatlah luas dan tidak terpaku pada satu objek saja. Public relations(PR) sangat menentukan kelangsungan hidup suatu lembaga atau perusahaan, karena public relations berperan untuk menumbuh kembangkan hubungan yang baik antara setiap organisasi dengan masyarakat atau publik sebagai sasaran dari kegiatan public relations itu sendiri. Ketika kita melihat sejarah perkembangan Public Relations dibelahan dunia dari Abad ke-19 sampai sekarang ialah merupakan perubahan mental, kualitas, pola pikir, pola pandang, sikap dan pola perilaku secara nasioal/internasional, membangun kerjasama secara lokal, nasional, internasional dan saling belajar di bidang politik, ekonomi, sosial budaya,Iptek, sesuai dengan kebutuhan era global/ informasi

Disadari atau tidak, dengan banyaknya lembaga dan perusahaan yang semakin bertumbuhan, persaingan yang semakin ketat dalam merebut perhatian masyarakat semakin gencar dan sering dilakukan. 
Masyarakat tentu lebih tertarik pada tawaran-tawaran program berkualitas yang dikemas dengan baik dan menarik.Apalagi berada dalam dunia informasi yang sangat cepat dan terbuka, sebuah lembaga atau perusahaan tidak mungkin hanya diam saja menunggu untuk mendapatkan perhatian public.

Humas akan selalu bertanggung jawab apabila citra pada lembaga atau institusi berdampak buruk dan juga sebaliknya humas harus bisa membangun citra yang baik/positif pada lembaga/institusi tersebut. "Jika suatu saat terjadi sesuatu yang bersebrangan dengan citra yang sudah disusun atau respon buruk masyarakat, Public Relatinharus bertanggung jawab memberikan masukan terhadap atasan atau to manajement", maka dari itu pada saat ini tidak bisa ditawar - tawar lagi kalau fungsi dan peranPublic Relation/Humas wajib diberdayakan.

Pertanyaan yang masih terbenak dalam pikiran kita ialah sampai mana Humas/Public Relation yang ada pada lembaga kita bisa mengatasi krisis manajemen? (1) Bagaimana kekuatan Public Relation/Humas di dalam menyusun, mengomunikasikan dan memanajeprogramlembaga itu sehingga bisa menumbuhkan respon masyarakat/publik?, (2) Bagaimana caranya untuk membangun komunikasi pada institusi/lembagadalam mengolah reputasi yang akan dikomunikasikan ke masyarakat/publik?, (3) Bagaimana caranya untuk membangun kinerja civitas academika di dalam lembaganya berjalan dengan apa yang dibutuhkan masyarakat/public ?

\section{Kesimpulan}

Akhirnya kita dapat menarik kesimpulan bahwa manajemen humas muncul berkenaan dengan sebuah metode " Public Relations" ketika menghadapi puncak krisis pada tahun 1906 yang mana pada saat itu terjadilah aksi mogok kerja para buruh diindustri pertambangan batu bara di Amerika Serikat.

Pada saat itu Ivy Letbetter Lee yang notabene seorang jurnalis muncul sebagai Tokoh Public Relation/ Humas untuk pertama kalinya. Beliau merekomendasikan manajemen humas sebagai solusi untuk mengatasi permasalahan yang sedang terjadi di industry batu bara tersebut akibat mogok masal para pekerja yang meminta kenaikan gaji.

Jadi yang dimaksud dengan manajemen humas ialah proses perencanaan , penelitian,aktualisasi dan pengontrolan atau pengawasan suatu kegiatan yang didalangi oleh sebuah organisasi baik itu dari internal atau ekternal.

Proses manajemen humas hanya bisa dijalankan oleh praktisi atau beberapa unsur yang memang benar benar sesuai dengan tujuan dan fungsi dari masing - masing bidang dimana hal ini sudah diatur dan disesuaikan dengan ruang lingkupnya masing-masing.

Evaluasi pelaksanaan suatu program, tidak semata-mata hanya dilihat melalui hasil akhirnya, akan tetapi evaluasi juga dapat dilihat dari segi pelaksanaannya. Hal ini dikemukakan oleh Grunig dan Hunt bahwasecara garis besar, evaluasi program humas dibedakan menjadi dua jenis yaituprocess evaluation (evaluasi proses) dan outcomes evaluation (evaluasi hasil). 


\section{DAFTAR PUSTAKA}

Afifa, N U R Shaff, Lidya Wati Evelina, and Dra Mm, 'Strategi Public Relations Dalam Membangun Customer Relationship Management Di Pt . Sungwon Button Indonesia', 2012

Baharun, Hasan, Management Of Quality Education In Pesantren: The Study of the Education Quality Improvement Pesantren by Strategy Management Approach (Malang: 2nd INTERNATIONAL CONFERENCES ON EDUCATION AND TRAINING (ICET), UM Malang., 2016)

Baharun, Hasan, 'Manajemen Kinerja Dalam Meningkatkan Competitive Advantage Pada Lembaga Pendidikan Islam', At-Tajdid: Jurnal Ilmu Tarbiyah, 5 (2016), 243-62

Baharun, Hasan, 'PENDIDIKAN ANAK DALAM KELUARGA; TELAAH EPISTEMOLOGIS', Pedagogik, 3 (2016), 96-107

Baharun, Hasan, 'Penilaian Berbasis Kelas Pada Pembelajaran Pendidikan Agama Islam Di Madrasah', MODELING: Jurnal Program Studi PGMI, 2016

Dr.Abdul Rahmad, MANAJEMEN HUMAS (Media Akademi Ruko Jambusari 7A Yogyakarta 55283, 2016)

Fauzi, Ahmad, 'Diskursus Pemikiran Dan Model Pengembangan Budaya Organisasi Noble Industry Di Lembaga Pendidikan Islam', Studi Islam Madinah IAI Tabah, 16 (2016)

Fauzi, Ahmad, 'Membangun Epistemologi Pendidikan Islam Melalui Kepemimpinan Spiritual: Suatu Telaah Diskursif', Journal Empirisma, STAIN Kediri, Vol. 24 (2015), 155-67

Fauzi, Ahmad, 'Pengembangan Human Relation Perspektif Nilai-Nilai AlQur'an', Mutawatir UIN Sunan Ampel Surabaya, 1 (2015), 168-79

Hasan Baharun, Zamroni, Manajemen Mutu Pendidikan: Ikhtiar Dalam Meningkatkan Mutu Pendidikan Madrasah Melalui Pendekatan Balanced Scorecard (Tulungagung: Akademia Pustaka, 2017)

Ivancevich, John M., 'Human Resource Management' (International Edition. (New York: McGraw-Hill \& Irwin, 2001), p. 51

Masykuri, Nurul Candrasari, 'PERAN PUBLIC RELATION TAK SEKEDAR FUNGSI TEKNIS', HUMANIORA, 2 (2011), 353-59

Mundiri, Akmal, 'KOMITMEN ORGANISASIONAL SUMBER DAYA MANUSIA DALAM MENINGKATKAN MUTU PENDIDIKAN PESANTREN', Pedagogik, 3 (2015), 88-105

Mundiri, Akmal, 'Organizational Culture Base On Total Quality Management In 
Islamic Educational Institution', ADRI International Journal Of Islamic Studies and Social Sciences, 1 (2017), 1-11

Mundiri, Akmal, 'STRATEGI LEMBAGA PENDIDIKAN ISLAM DALAM MEMBANGUN BRANDING IMAGE', Pedagogik, 3 (2016), 58-72

'National Study Committee on Evaluation Dalam Stark Dan Thomas (1994:12) Lihat Juga Jody Fitzpatrick. Evaluation in Action: Interviews With Expert Evaluators.' (Los Angeles: SAGE Publication, 2009), p. 43

R.L. Thorndike and E.P.Hagen, 'Measurement and Evaluation in Teaching .' (Englewood Cliffs New Jersey: Prentice-Hall, Inc, 2009), p. 123

Rosady, Ruslan, Praktik Dan Solusi Public Relations Dalam Situasi Krisis Dan Pemulihan (citra.Jakrta:Gahlia Indonesia, 1997)

Schermerhorn, John R., Jr, 'Management Eighth Edition.' (New York: John Wiley \& Sons, Inc, 2005), p. 15

Stoner, James, A.F., Freemen , R.W. dan Gilbert, 'Management' (Pritice-Hall, New Jeresey., 1996), p. 120

Trisakti, Yayasan, Dasar - Dasar Manajemen (Jakarta:Grasindo, 2008) 